\title{
Hidronime din comuna Ocna Şugatag, județul Maramureș
}

\author{
Adelina Emilia Mihali* \\ Institutul de Lingvistică și Istorie Literară „Sextil Puşcariu”, Str. Emil Racoviță 21, 400165, Cluj-Napoca, România
}

\section{Despre articol}

Istoric:

Primit 6 iulie 2018

Acceptat 26 iulie 2018

Publicat 7 octombrie 2018

Cuvinte-cheie:

toponim

hidronim

antroponim

nume de familie

model toponimic

\begin{abstract}
Rezumat
Articolul este o analiză a hidronimelor din comuna Ocna Șugatag, județul Maramureș, fiind parte a unei cercetări mai ample asupra toponimiei maramureșene. Amplasat într-o zonă deluroasă, la poalele munților Gutîi, pe cursul rîului Mara, hotarul celor patru localități componente ale comunei, Breb, Hoteni, SatȘugatag ş,i Ocna Șugatag, se caracterizează printr-o vastă rețea hidronimică, văi și izvoare, afluenți ai Marei, dar și fîntîni, lacuri și mlaştini. Corpusul lucrării a fost extras din materialul toponimic cules prin anchete de teren, nepublicat pînă în prezent. Numele topice sînt tratate individual, pentru fiecare hidronim precizîndu-se răspunsurile informatorilor, formele diferite, dacă este cazul, precum şi date suplimentare, cunoscute de noi, Ocna Şugatag fiind localitatea noastră natală. Scopul acestui demers este stabilirea etimologiei hidronimelor din arealul cercetat. Pentru o privire de ansamblu asupra hidronimiei și a antroponimiei care stă la baza ei, indicăm și ariile de răspîndire ale unor nume topice, limitîndu-ne însă la Transilvania, precum și frecvența numelor de familie pe județ. În urma analizei etimologice a toponimelor care denumesc ape, acestea sînt clasificate din punct de vedere structural, pentru a ilustra modelele sintacticomorfologice identificate. Concluzia noastră susține faptul că hidronimele din comuna Ocna Șugatag, județul Maramureș, reflectă relațiile de proprietate, precum și caracteristicile geomorfologice și geologice ale locului.
\end{abstract}

\section{Introducere}

Cu o stabilitate mai mare în limbă decît apelativele sau antroponimele, toponimele, în special hidronimele, „se păstrează deseori cu o mare tenacitate, chiar și la schimbarea populației” (Frățilă, 2002, p. 72). Astfel, numele apelor și ale masivelor muntoase sînt considerate anterioare celorlalte nume topice, însă există situații în care acest principiu este încălcat, în special în cazul numelor de apă care au la bază un antroponim (Bolocan, 1975, p. 383).

Lucrarea noastră are ca scop analiza toponimelor care denumesc ape (rîuri, văi, izvoare, lacuri, mlaștini) din comuna natală, Ocna Șugatag, județul Maramureș. Corpusul care stă la baza articolului a fost extras din materialul toponimic cules prin anchete directe pe teren ${ }^{1}$, nepublicat pînă în prezent, făcînd parte dintr-o cercetare mai amplă asupra toponimiei maramureșene. Numele topice au fost literarizate, dîndu-se transcrierea fonetică acolo unde sînt evidente particularitățile fonetice ale graiului local.

Comuna Ocna Șugatag, situată în Depresiunea Maramureșului, pe interfluviul dintre rîurile Mara și Cosău, la poalele estice ale Munților Gutîi, în partea nordică a județului Maramureș, este alcătuită din localităţile Ocna Șugatag (centrul comunei), Breb, Hoteni și Sat-Șugatag. Prima atestare documentară a localității Ocna Șugatag datează din 1355 sub forma fodina salium, cînd se face referire la un drum pe care se duce sare în Austria și care trece prin apropierea satului Giulești. Alte denumiri sau forme sub care apare menționată localitatea în documente sînt: Zalatnya Sugatag 1360; Sugatag 1419; Akna Sugatag

*Adresă de corespondență: adelinatatar@yahoo.com.

${ }^{1}$ Anchetele au fost efectuate în vara anului 2017, sub coordonarea domnului Dumitru Loșonţi, CS I dr. în cadrul Institutului de Lingvistică și Istorie Literară „Sextil Pușcariu”, Cluj-Napoca. Redăm lista informatorilor, ale căror răspunsuri au fost folosite de noi: I. Birtoc Petru, 64 de ani, agricultor, Sat-Șugatag; II. Hotea Ioan, 53 de ani, om de serviciu, Hoteni; III. Chira Ana, 50 de ani, casnică, Hoteni; IV. Borca Ioan, 71 de ani, miner, Breb; V. Tătar Gheorghe, 57 de ani, miner, Ocna Șugatag. 
1828. Pentru un an (1991-1992), comuna a purtat numele de Ocna Maramureșului, revenindu-se apoi la denumirea anterioară, Ocna Sugatag ${ }^{2}$.

În 1360 este atestată localitatea Sat-Şugatag (Zalatyna, villa olachalis Sugatag-falva, Swgathakfalwa), ale cărei denumiri anterioare (Sugatagh 1365, Sugathagh 1459, utraque Swgathak 1472 - pentru SatȘugatag și Ocna Șugatag, Sugatagh 1828, Sugatag 1851) reflectă legătura cu salina de la Ocna Șugatag. Determinantul Șugatag a fost interpretat diferit: Ștef(2016, p. 159) susține opinia lui Papahagi (1981, p. 156, la note), conform căruia numele topic provine din magh. sóvago 'tăietor de sare' + germ. Tage 'zilier', mai ales că Sat-Șugatag ,e considerat ca fiind locuit de oameni lucrători cu ziua, care nu sînt «ńemńeșin»”; Kiss (1988, p. 64, s.v. Akna Sugatag) îl consideră derivat de la vb. súg 'a șopti' cu suf. -atag, părere cu care sîntem de acord și noi.

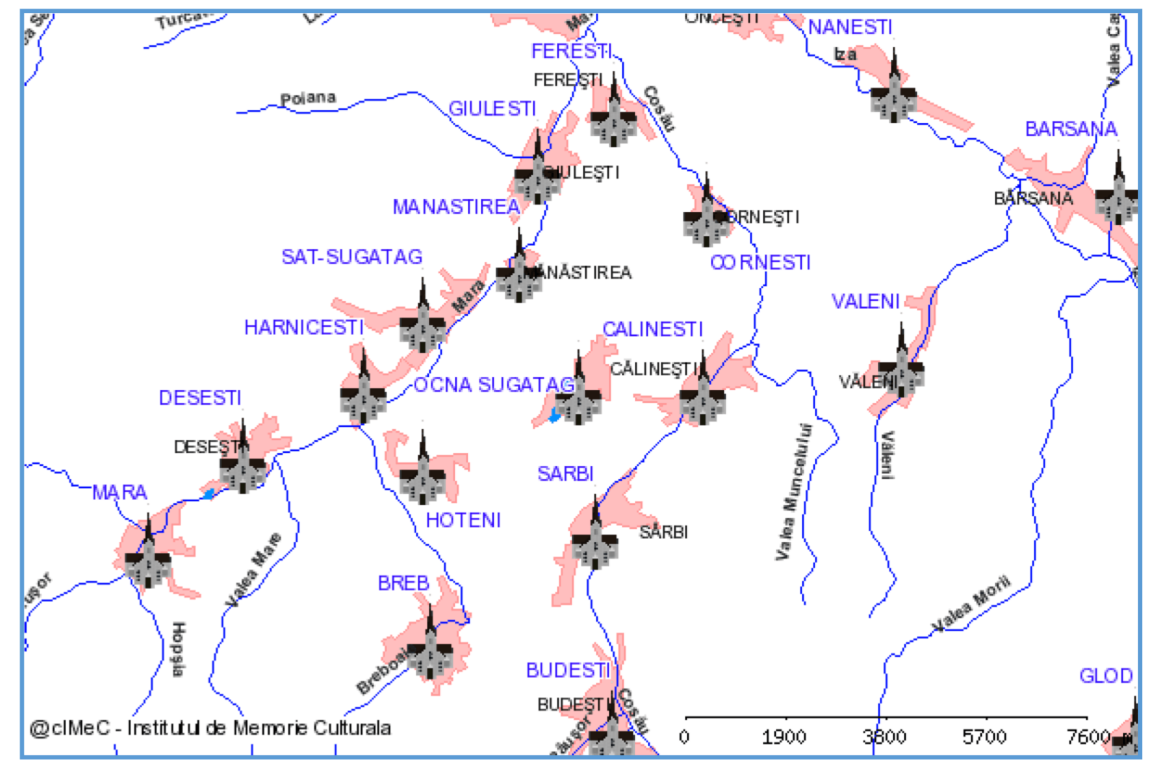

Localitatea Hoteni, atestată în 1360 (Zalatina), alături de Breb (Hódpatakfalwa, villa olachalis Hatpatokfalva), apare menționată abia în 1555 cu numele Hotynfalwa. Oiconimul Hoteni provine din numele de grup hoteni < n. fam. Hotea + suf. -eni. Numele Bréb este înregistrat în documente începînd cu 1715 și are la bază apelativul breb 'castor'.

\section{Nume topice care denumesc ape}

Fiind situat într-o zonă deluroasă, arealul cercetat abundă în cursuri de apă, mai mari sau mai mici, afluenți ai rîului Mara, în izvoare sau ape stătătoare. Numele acestora indică relaţii de proprietate sau aspecte ale apei. Din punct de vedere semantic, hidronimele din comuna Ocna Șugatag pot fi grupate în patru clase: 1. nume de rîuri, 2. nume de văi, 3. nume de izvoare mici, fîntîni și 4 . nume de ape stătătoare.

\subsection{Nume topice care denumesc rîuri}

MÁRA (H, S), afluent de stînga al Izei, avînd o lungime de 40 de km, cunoscut, în Hoteni, cu termenul generic Rîu. Etimologia numelui a fost intens discutată, cea mai plauzibilă pare a fi aceea care pornește de la radicalul mar - 'apă' (+ $-a$,considerat ca feminin articulat” sau ca „sufix toponimic”), cf. sanscr. mara, celticul mor, goticul marei, latinul mare, slavul mare, lituanianul mares (Xenopol, 1985, p. 50-51), care ar sta și la baza hidronimului Mureș.

Rî́U BRÁZILOR (S), denumire sub care este cunoscut cursul superior al rîului Mara; izvorăște de sub vîrful Pleşca, ,izvorăște din Braz, din pășune” I, fiind format de trei cursuri de apă mici, Valea Răchiții, Valea Seacă și Valea Podului, trece prin Cheile Tătarului, acumulînd celelalte văi din zona montană, Vidrişca, Tălhărașu, Valea Roșie și Valea Șteviei. - Din rîu + n. top. Brazi < brad (pl. brazi).

\footnotetext{
${ }^{2}$ Denumirile anterioare ale localităților anchetate au fost date după Suciu (1967 și 1968).
} 


\subsection{Nume topice care denumesc văi}

BĂRCOȚEÁSCA (S). - Din adj. substantivizat bărcoțeasca < n. p. Bărcotă (vezi DoR, p. 199) + suf. -easca. În Borșa, MM, se întîlnește supranumele Bîrcotă, consemnat și în toponimie (vezi Mihali, 2015, p. 137, 161).

BREBOÁIA (B), afluent al Marei, „izvorăște din Măgură” IV. - Din suprn. Breboaia < n. p. Breb, cu 5 menționări ca nume de familie în județ ${ }^{3}$, sau din breboaia 'femela brebului'.

BREBOÍŢA (B) IV. - Din n. top. Breboaia + suf. dim. -iţa.

CÎRSTOÁIA (S), „o văliucă, se varsă în rîu [Mara]” I. - Din suprn. Cîrstoaia < n. p. Cîrstea + suf. -oaia.

CîCÁCEA (S), altă denumire sub care este cunoscută Cîrstoaia, I. - Din por. Cîcacea. Cf. n. top. Căcîcea (Vişovan, 2005, p. 31; TTRT-Valea Hășdății, p. 35).

COPĂCíș (B), ,vîlcea” IV. - Din n. top. Copăciş, fînaț < copăciş ‘loc cu mulți copaci’ < copac + suf. col. $-i s ̧$.

DĂRÁSCA (B, H, O, S), „valea ce vine de la Hoteni” I, „vale” III, V. - Din n. p. Dărasca ${ }^{4}$ < n. p. Daru (Iordan, 1983, p. 166; D OR, p. 102, n. p. Mardarie, p. 257, n. p. Dar, cu formele Dărescu, Dărești, Dărăști, Dărăscu) + suf. -(e)asca.

RUGINOÁSA [ruğînósa] (B), „vîlcelucă” IV. - Din adj. ruginos, -oasă '(despre un loc) cu apă ruginie’. Hidronimul se regăsește și în alte zone ale Transilvaniei (Vişovan, 2005, p. 311; TTRT-Sălaj, p. 282; TTRT-Valea Hășdății, p. 101).

SĂRÁTA (O), V. - Din adj. substantivizat sărat, -ă 'cu sare, bogat în sare’. Deși valea are apa dulce, ea traversează o regiune bogată în sare de unde își colectează apa. În Maramureș, numele topic este înregistrat și în alte zone cunoscute pentru zăcămintele de sare (vezi Vişovan, 2005, p. 315).

SUNĂTOÁREA (B), ,valea de la intrarea în sat” IV. - Din adj. substantivizat sunător, - oare 'care produce, care emite sau care propagă sunete’. Numele este atribuit, de regulă, apelor curgătoare care formează, pe cursul lor, cascade (vezi Iordan, 1963, p. 58). În Maramureș, numele topic este înregistrat și în localitatea Strîmtura (Vișovan, 2005, p. 334).

TĂLHĂRÁȘU (S), ,izvorăște din pădure de la Pleșca, vine în Cheile Tătarului și se varsă în Valea Roșie” I. - Din tălhăraş < tălhar, var. a lui tîlhar 'persoană care fură, pradă, jefuiește; hoț, bandit' sau por. Tălhăraş < tălhar 'om ticălos, rău, nemernic' + suf. -aș. Cf. n. top. Tălhăroaia (Vișovan, 2008, p. 243).

TÎ́LBUREA [tî́lburea] (B, S), „o văliucă mică” I, „apă” IV. - Din adj. substantivizat tîlbure, variantă a lui tulbure '(despre ape) agitat, învolburat'. Toponimul are o răspîndire largă în Maramureș (Vişovan, 2005, p. 344; 2008, p. 245).

VÁLEA BORCÚTULUI (B), ,urcă pînă la Budești” IV. - Din vale + n. top. Borcut (vezi infra).

VÁLEA CÁSELOR (B), „vale la intrarea în sat, se varsă în Breboaia” IV. - Din casă (pl. case).

VÁLEA CHÉII $(S)$, „coboară de sus de la Iezăr”, „Valea Iezărului și Valea Horjii formează Valea Cheii după ce trec prin Cheie” I. - Din n. top. Cheia < cheie „vale care șerpuiește între doi pereți de stîncă și care deschide trecerea într-o vale sau la șes între două țări ori ținuturi; strîmtoare” (MDA).

VÁLEA HÓRJII (S), ,izvorăște dintr-o móciră di su Vîrvu lu Ștefan; apă cam mociroasă” I. - Din n. top. Horja < din n. fam. Horja, cu 34 de purtători în județ.

VÁLEA IÉZERULUI (S), ,vine din Iezăr”. - Din n. top. Iezer < iezer 'lac de munte'.

VÁLEA LU TODORÚȚ (S), ,izvorăște din Piatra Mică, se duce în hotarul Giuleștiului” I. - Din hip. Todoruţ < n. p. Todor, var. a lui Teodor. Ca nume de familie, Todoruţ înregistrează 30 de purtători în Maramureș.

\footnotetext{
${ }^{3}$ Frecvența numelor de familie în județ este dată după DFNFM.

${ }^{4}$ Antroponimul Dărasca apare consemnat în registru de nașteri din 1923, în localitatea Breb.
} 
VÁLEA MÁNDRULUI (S), ,vine de su Preluca Iurii și se varsă în Valea Podului” I. - Din n. fam. Mandru (vezi Iordan, 1983, p. 289). Cf. n. fam. Mandra, frecvent în localitate, cu 112 de ocurențe în Maramureș. VÁLEA MÁRE (B, H), ,vale cătă Mara, se varsă în Mara” II, „vine de la Gutin, merge la Desești în rîu” III, „apă de sub Gutin” IV. - Din adj. mare.

VÁLEA MISÁRĂȘULUI (S). - Din n. p. Misarăşs. Numele de familie Misarăşsare o menționare, Misaraş - două înregistrări, Misaroș - 26 de menţionări, însă Mesaroş are 270 de apariții, fiind frecvent în Sat Şugatag.

VÁLEA NICHITÉȘTIULUI [ ńit'it'éșt'ului] (B) IV. - Din n. top. Nichitești < n. grup. nichitești < suprn. Nichita, înregistrat în prezent în localitate. Ca nume de familie, Nichita are frecvența 143 in județ. VÁleA PÓdULUI (S), I. - Din n. top. *Pod < pod 'platou, terasă' (Iordan, 1963, p. 33).

VÁLEA PÓPII (H), „vale mică” II. - Din popă 'preot'.

VÁLEA RĂCHÍȚII (S), „vine de la Răchita din Giulești”. - Din n. top. Răchita < răchită 'salcie’.

VÁLEA RÓŞIE (S), „izvorăște din pădure, de pă su Pleșca”. - Din adj. roșu, -ie.

VÁLEA SEACĂ (S), I. - Din adj. sec, seacă 'care nu (mai) are apă, din care a dispărut apa (definitiv sau temporar)'.

VÁLEA ȘTÉVII [válea ștéd'i] (S), „vine din Ștevea” I. - Din n. top. Ștévea < din șteve, var. a lui ștevie 'numele mai multor plante erbacee' (DLR).

VĂLCEÁUA CĂȚÉLII [vălčáua cățélii] (H), II, „se formează cîte o vîlcea cînd plouă” IV. - Din vălcea, var. a lui vîlcea 'pîrîu mic' + cățea 'femela cîinelui'.

VĂLCEÁUA CRÁMELOR (B), „în Crame, se varsă în Valea Mare” IV. - Din n. top. Crame < cram (pl. crame), var. a lui crámă 'colibă, acareturi, dependințe în jurul casei' (vezi și TTRT-Sălaj, p. 89).

VĂSCOÁIA (S), „o văliucă ce se varsă în Valea Răchiții și izvorăște din Între Rude, de Su Vîrv” I. - Din suprn. Văscoaia < n. p. Vasc(u), neînregistrat în prezent în localitate, prezent însă în Maramureș: Vasc 57 de purtători, Vascu - 5, Vascul - 101, Vasko - 8.

VÎLCEÁ (B), „se varsă în Breboaia” IV. - Din vîlcea.

VIDRÍșCA (S), ,izvorăște din pădure de la Pleșca, vine în Cheile Tătarului și se varsă în Valea Roșie” I. posibil din hip. Vidrişca < n. p. Vidra (DoR, p. 405; Oancă, 2016, p. 130) + suf. -işcă (vezi Pascu, 1916, p. 249-250) sau din sl. vydriška.

\subsection{Nume topice care denumesc fintîni, izvoare}

BORCÚT (B), ,izvor cu apă minerală” IV. - Din borcut 'apă minerală. Numele topic este răspîndit în județ (vezi Mihali, 2015, p. 60; Vișovan, 2005, p. 24; 2008, p. 21).

CIURGẮU (O), V. - Din ciurgău 'scoc sau teavă prin care curge apa unui izvor'. Pentru răspîndirea toponimului, vezi și TTRT-Valea Hășdății, p. 39; TTRT-Valea Ierii, p. 41; TTRT-Sălaj, p. 73; Vişovan (2005, p. 36; 2008, p. 34).

CIURÓI (H), „izvor” II. - Din ciuroi 'izvor care curge pe un scoc îngust de scoarță pus anume, ciurgău, șipot, jghebuleț etc.' (DLR). Vezi și Mihali (2015, p. 107); Vişovan (2008, p. 37, p. 34); TTRT-Sălaj, p. 70. FÎNTÎ́NA CIÓTULUI (S), I. - Din fintînă „izvor” + suprn. Ciotu.

FÎNTÎ́NA CU SOLOMÎ́ZDRĂ (O), V. - Din reg. solomîzdră, var. a lui salamandră 'specie de animal amfibian din ordinul caudatelor, asemănător cu șopîrla, cu picioarele scurte și îndreptate în lături, cu corpul turtit și lat, cu pielea de culoare neagră cu pete galbene, cu tegumentul lucios care secretă o substanță iritantă cu rol protector' (DLR).

FÎNTÎNA DE SLÁTINĂ (O), lac mic cu apă sărată sub forma unui puț alimentat de un izvor salin, loc de unde localnici aduc slatină, „un puț cu slatină” V. - Din prep. de + subst. slatină 'apă sărată'.

FÎNTÎNA DE LA DÎMBURÉLE (B). IV. - Din prep. de la + n. top. Dîmburéle < dîmburel (pl. dimburele). 
FÎNTÎ́NA HÚCIULUI (B), ,fîntînă la rădăcina unui arin, la intrarea în Huciu Des” IV. - Din n. top. Huciu $[$ Des] < buci 'huceag'.

FÎNTÎ́NA IÉDULUI (S), izvor, „zice că acolo la o piatră au auzit iedul zbierînd” I. - Din ied 'puiul de sex bărbătesc al căprioarei. Cf. antrop. Iedu.

FÎNTÎ́NA LU CÎRNÁT, (S), I. - Din por. Cîrnaţ, prezent ca supranume și în Hoteni.

FÎNTÎNA LU DRÎ́DU (S), I. - Din por. Drîdu.

FÎNTÎNA LU GÁBOR (H), „fîntînă” II. - Din n. p. magh. Gabor 'Gavril', întîlnit în arealul cercetat ca prenume, atît în trecut, cît și în prezent. Numele de familie Gabor are 120 de menționări în județ.

FÎNTÎ́NA LU HÁȘTOR (S), „izvor puternic, între Laz și Văratec” I. - Din n. p. Hastor, posibil un nume evreiesc.

FÎNTÎNA LU PĂPÚC (S), I. - Din sprn. Păpuc. N. fam Papuc figurează în Maramureș cu 9 purtători.

FÎNTÎ́NA LU ȘTET, (S), „e su Cheie, su Piatra Mare” I. - n. fam. Șteț, frecvent în Sat-Șugatag, cu 167 de purtători în Maramureș.

FîNTÎ́NA LU TÓDOR (S), „, în Horja, apă bună” I. - Din n. p. Todor, var. a lui Teodor. N. fam. Todor este înregistrat în Maramureș pentru 51 de persoane.

FîNTÎNA LU VASALÍ-A MOÁȘII [fîntîna lu vasalíî-a mơșî] (S), „e su Piatra Mare” I. - Din pren. Vasalie, var. pentru Vasile + suprn. A Moașii.

FîNTÎNA MÁNCIULUI (S) I. - Din n. fam. Manciu, cu 52 de purtători în Maramureș. Astăzi, numele de familie nu este cunoscut în localitate.

FÎNTÎ́NA MẮGURII (B), ,izvor pe Măgura” IV. - Din n. top. Măgura < măgură 'deal înalt și lin, rotund'.

FÎNTÎ́NA PRÉLUCILOR (S), „apă cu lăturiș`” I. - Din n. top. Préluci < prelúcă (pl. preluci) ‘poiană mică' (DLR).

ȘTIUBÉI (H), „fintînă” III. - Din știubei ‘fîntînă cu izvor la mică adîncime, care are ca ghizd un știubei (3); prin. gener. fintînă puțin adîncă; izvor al unei ape curgătoare' (DLR). Toponimul se întîlnește și în alte zone ale Transilvaniei (TTRT-Sălaj, p. 305; TTRT-Valea Ierii, p. 163; TTRT-Valea Hășdăţii, p. 107).

\subsection{Nume topice care denumesc ape stătătoare}

BÁLTĂ (B, H), „se topea cînepa, e între Hoteni și Breb” IV. - Din baltă întindere (mai mare) de apă stătătoare, naturală geologic, cu adîncime mică, cu vegetație și faună acvatică specifică (MDA).

GÁBORI (O), lac cu apă dulce, rezultat în urma surpării minei de sare, „tău mare” V. - Din magh. Gábori < n. p. magh. Gabor. Lacul păstrează ultima denumire a ocnei.

IÉZER (S), I. - Din iezer 'lac de munte' (vezi și Mihali, 2015, p. 97; Vişovan, 2005, p. 149; 2008, p. 121). LÁCU RÓȘU (O), lac cu apă sărată, denumit astfel după culoarea arămie a apei, V. - Din lac + adj. roşu. LÁCU VRĂJITOÁREI (O), lac cu apă sărată, V. - Din vrăjitoare. Toponimul este dat pe baza aspectului sălbatic pe care lacul îl are. Versanții gropii, în care se află cantonat, sînt foarte abrupți și acoperiți de vegetație bogată (copaci, tufe de soc, alun, urzici etc.), ce formează hățișuri de nepătruns, mai ales vara. Întrucît și oglinda lacului este acoperită de lintiță, tot complexul acesta de factori dă lacului un aspect sălbatic, vrăjitoresc, inspirînd teamă celui ce pătrunde pentru prima dată spre el.

MÓCIRA (H, S), „mociră mare” I, „1̂i mociros” II, „teren mociros” III. - Din mociră ‘loc apos, mlăștinos, noroios; mocirlă.

\footnotetext{
${ }^{5}$ Pentru lăturiş, informatorul I a oferit următoarea explicație: „e un vierme, are picioare multe și-i lat și cînd merge se îndreaptă; se găsește în loc pietros, unde izvorul e mai pietros, nisipos, în apă rece de munte”, ,apa cu lăturiș îi bună”. Cuvîntul lăturiş nu este cuprins în dicționare cu sensul precizat de informator, însă MDA glosează termenul lătunoi, var. pentru lătunoaie '(reg.) specie de insectă care trăiește în fundul apelor (Gumarus Pulex)'. Colega noastră, Veronica Vlasin, ne-a confirmat prezența temenului lătunoi, cu sensul precizat de informator pentru lăturiş, în graiul din localitatea Cozla, jud. Sălaj.
} 
MÓCIRA ÁlbULUI (B), „teren mociros” IV. - Din n. p. Albu. N. fam. Albu are 186 de purtători în Maramureș.

MÓCIRA CU LÚȘTELE (S), „se fac luști multe primăvara” I. - Din prep. cu + luşte 'numele a două plante erbacee din familia liliacee, cu frunze lineare, cu flori mari verzui pe dinafară și albe în interior, dispuse într-un racem dens' (DLR).

MÓCIRA DIN LAZ (S), I. - Din prep. din + n. top. Laz<laz'teren obținut prin tăierea pădurii, prin lăzuire’.

MÓCIRA MÁRE (S), parte a pășunii, „îi mociră, se scaldă bivolii” I. - Din adj. mare.

ÓREGHI [óreǵi] (O), lac cu apă sărată, rezultat în urma surpării minei de sare, „tău sărat” V. - Din n. fam. magh. Oreg, atestat de la 1554 < magh. öreg „bătrîn” (Kázmér, 1993) sau direct din magh. öreg 'bătrîn'. În lucrările de geologie sau în articolele turistice, apare și denumirea românească, Lacul Bătrîn, datorată faptului că este cel mai vechi lac din localitate folosit pentru scăldat. Localnicii, indiferent de etnie, folosesc numele Oreghi.

TĂU (H), „sînt tăurile de la Hoteni; se topea cînepa” II, „tău hotenarilor” III. - Din tău 'lac de munte'. Vezi Baltă.

TẮU CHENDROÁII (B), TẮU CRENDOÁII, „tău cu muști su Piatra Mare” IV. - Din suprn. Chendroaia < n. p. Chendre (a) sau Chender (Iordan, 1983, p. 112) + suf. -oaia. În Maramureș, n. fam. Chender are frecvența 7, Chendre (a) nu este înregistrat în DFNFM, însă figurează Chendrean cu 7 purtători. Forma Tău Crendoaiei oferită de informatorul IV este o variantă cu metateză.

TẮU CRĂCIÚNII (B), IV. - Din n. p. Crăciuna (vezi DoR, p. 36). Crăciuna nu figurează ca nume de familie în Maramureș, conform DFNFM, însă n. fam. Crăciun are frecvența 607 ca nume de familie în județ.

TẮU MORĂRÉNILOR (B), IV. - Din n. grup. Morăreni < n. p. Morar + suf. -eni. N. p. Morar este întîlnit în zonă atît ca nume de familie, cu frecvența 777 în Maramureș, cît și ca supranume.

TĂU SĂRÁT (B), IV. - Din adj. sărat „cu apă sărată”.

TẮUL FẮRĂ FUND (O), V. - Din prep. fără + fund 'limita de jos'. Lacul este denumit astfel, deoarece, fiind cel mai adînc lac de la Ocna Șugatag $(32,9$ m), încercările unora de a-i determina adîncimea cu mijloace rudimentare nu au dat rezultate. Localnicii mai justifică acest nume printr-o legendă conform căreia în acest lac s-ar fi înecat un om cu tot cu carul tras de bivoli și, întrucît nimic nu a mai apărut la suprafață, ,înseamnă că lacul nu are fund”.

\section{Considerații lingvistice}

În arealul cercetat de noi, hidronimul Mara aparține celui mai vechi strat toponimic, avînd la bază un radical indo-european. În majoritatea lor, toponimele discutate sînt românești, excepție făcînd numele celor două lacuri din Ocna Șugatag, formate prin surparea vechilor saline, Gabori și Oreghi, forme genitivale maghiare ale unor nume de persoană. Contactul lingvistic se resimte însă la nivel fonetic, în deplasarea accentului pe prima silabă în toponimele Mócira și Préluci (Fîntîna Prélucilor), consecință a influenței limbii maghiare, vorbită și astăzi în arealul cercetat.

Din punct de vedere structural, numele topice care denumesc ape din comuna Ocna Şugatag, jud. Maramureș, reflectă modele sau tipuri toponimice în care se evidențiază contribuția diferitelor părți de vorbire la realizarea inventarului toponimic, precum și frecvența unor structuri sintactice. Astfel, numele topice simple au la bază:

- substantive cu formă de singular: Baltă, Borcut, Ciurgău, Ciuroi, Iezer, Móciră, Știubei, Tău, Tălhăraş, Vîlcea;

- adjective care indică o caracteristică a apei: Ruginoasa, Sărata, Sunătoarea, Tîlburea. Adjectivele însoțeau, într-o primă fază, un determinat (ex. Valea Sărată), iar prin elipsa acestuia și prin articularea formei s-au substantivizat. 
- derivate cu sufixul colectiv -iş: Copăciş, sau diminutival -iță de la un alt nume topic: Breboiţa, ultimul indicînd un raport de mărime între două cursuri de apă apropiate ca spaţiu. Unele hidronime provin din nume de persoană feminine create de la antroponime masculine cu sufixul-oaia (Cîrstoaia, Văscoaia) sau suf. -easca (Dărasca), ori au la bază o poreclă (Cîcacea).

Cele mai multe nume topice sînt, însă, compuse din două sau mai multe elemente lexicale, cu un sens unitar și funcție denominativă comună. Cel mai bine reprezentat model tipologic este cel cu determinantul în genitiv, indicînd posesia sau apartenența la o regiune, zonă. Astfel, determinantul poate fi apelativ, antroponim sau alt toponim. În structurile denominative Fîntîna Iedului, Lacu Vrăjitoarii, Valea Caselor, Valea Cățelii, Valea Popii, determinantul, nume comun în genitiv, trimite fie la posesie (Valea Popii), fie la un aspect remarcabil în fauna zonei (Valea Iedului) sau la o caracteristică a arealului în care este situat obiectul geografic astfel numit (Valea Caselor).

Cele mai multe structuri topice genitivale au un determinant antroponimic - nume de familie (Fîntîna lu Șteț, Fîntîna Manciului, Valea Mandrului), supranume (Fîntîna Ciotului, Fîntînalu Cîrnaț, Fîntîna lu Păpuc), poreclă personală (Fîntîna lu Drîdu), antroponim feminin (Tău Chendroaii), nume de grup (Tău Morărenilor), nume de botez + supranume (Fîntîna lu Vasali-a Moașii). În unele situații, este greu de stabilit dacă toponimul are la bază un nume de familie sau un prenume, ori un supranume, deoarece antroponimul circulă în toate cele trei forme (Fîntîna lu Gabor, Fîntîna lu Todor, Mócira Albului, Valea lu Todoruț, Valea Misárăşului) sau este întîlnit atît ca prenume, cît și ca supranume (Tău Crăciunii). Articularea determinantului antroponimic se face enclitic, cu articol feminin sau masculin (Fîntîna Ciotului, Mocira Albului, Tău Crăciunii, Valea Mandrului, Valea Misarășului) sau proclitic (Fîntîna lu Haștor, Fîntîna lu Gabor).

A treia subclasă a modelului tipologic substantiv + substantiv în genitiv cuprinde numele de locuri care conțin în structura lor un determinant toponimic. În această situație, genitivul indică poziția în teren, apartenența obiectului geografic denumit la un areal mai mare (Fîntîna Huciului, Fîntîna Măgurii, Fîntîna Prelucilor, Valea Cramelor, Valea Cheii, Valea Horjii, Valea Nichiteştiului) sau proveniența (Valea Iezerului, Valea Răchiții, Valea Ștevii).

Un alt model tipologic regăsit în hidronimia arealului cercetat este substantiv + prepoziție + substantiv, fie apelativ (Fîntîna cu Solomîzdră, Fîntîna de Slatină, Mócira cu Luștele, Tău fără Fund), fie nume topic (Fîntîna de la Dîmburele, Mócira din Laz). Prepozițiile $c u$, de, fără indică, în acest context, o caracteristică a apei sau a locului, iar din și de la exprimă poziția geografică a apei în raport cu un alt obiect geografic mai mare și mai bine cunoscut.

Hidronimele create după modelul substantiv + adjectiv nu sînt numeroase în arealul cercetat, însă sînt un reper important în stabilirea unor caracteristici ale solului și ale apei. Determinantul adjectival oferă informații legate de culoarea apei (Lacu Roșu, Valea Roșie), de calitatea apei (Tău Sărat, Valea Seacă) sau de mărime (Mócira Mare, Valea Mare). În cazul determinantului roşu, acesta denumește izvoare care trec prin zone bogate în fier (vezi și Ruginoasa), sau cu o concentrație mare de sare care dă o nuanță arămie apei.

Hidronimele discutate ilustrează faptul că toponimele, ca elemente ale lexicului, se supun acelorași procedee de compunere ca numele comune, valorificînd toate structurile limbii.

\section{Concluzii}

Cercetarea de față a evidențiat faptul că hidronimele din comuna Ocna Șugatag, județul Maramureș, reflectă interdependența dintre toponimie și lexicul comun, pe de-o parte, și dintre toponimie și antroponimie, pe de altă parte. În cazul izvoarelor și al fintînilor din zona montană, relaţiile de proprietate sînt mai strînse decît în cazul cursurilor de apă mai mici sau mai mari, care aparţineau întregii comunități sau chiar mai multor colectivități umane. Astfel, izvoarele mici, situate adesea într-o zonă cu fînaț, deci într-un areal aflat în posesia unei familii, chiar dacă sînt utilizate de toți membri comunității, sînt denumite după 
proprietar. Prin această modalitate de denominație sînt conservate antroponime care au dispărut din localitate, ca urmare a mobilității purtătorilor (Drîdu, Haştor, Văscoaia), sau se pot identifica nume de familie frecvente, supranume vechi, porecle personale sau nume de botez. Din acest punct de vedere, hidronimia şi toponimia în general sînt radiografii ale antroponimiei României, atît sincronic, cît și diacronic, motiv pentru care glosarea și cercetarea lor devine o condiției sine qua non a cunoașterii identității de neam și a evoluției unei așezări umane.

\section{Bibliografie}

Bolocan, Gh. (1975). Stratificări în toponimie, în „Limba Română”, vol. XXIV, nr. 6, p. 383-385.

DFNFM = Vişovan, Ș., Farcaş, M., Frînc, M.S., Vișovan, S.S., Vișovan, M. \& Farcaș, S. (2007). Dicționar de frecvență a numelor de familie din Maramureș, Editura Universității de Nord, Baia Mare.

DLR = Dicționarul limbii române, seria nouă, București, 1965 și urm.

DOR = Constantinescu, N.A. (1963). Dicționar onomastic românesc, Editura Academiei Republicii Populare Române, București.

DTRO = Dicționarul toponimic al României. Oltenia, I, sub redacția prof. univ. dr. Gh. Bolocan, cu o Introducere de Gh. Bolocan, Editura Universitaria, Craiova, 1993.

Frățilă, V. (2002). Studii de toponimie și dialectologie, Editura Excelsior Art, Timișoara.

Iordan, I. (1963). Toponimia românească, Editura Academiei Republicii Populare Române, București.

Iordan, I. (1983). Dicționar al numelor de familie românești, Editura Științifică și Enciclopedică, București.

Kázmér, M. (1993). Régi magyar családnevek szótára XIV-XVII. század, Magyar Nyelvtudományi Társaság, Budapest.

Kiss, L. (1988). Földrajzi nevek etimológiai szótára, negedik, bövitett és javitott kiadás, I, II, Akadémiai Kiadó, Budapest.

MDA = Micul dicționar academic, vol. I-IV, Academia Română, Institutul de Lingvistică „Iorgu Iordan - Al. Rosetti”, Editura

Univers Enciclopedic, București, 2002 și urm.

Mihali, A.E. (2015). Toponimie maramureșeană. Valea superioară a Vișeului, Editura Mega, Cluj-Napoca.

Oancă, T. (2016). Microsisteme antroponimice româneşti, Editura Grafix, Craiova.

Papahagi, T. (1981). Graiul și folklorul Maramureșului, ediția a II-a, în Grai, folklor, etnografie, ediție și prefață de Valeriu Rusu, Editura Minerva, București.

Pascu, G. (1916). Sufixele românești, Librăriile Socec \& Co., C. Sfetea, Pavel Suru, București.

Suciu, C. (1967). Dicţionar istoric al localităților din Transilvania, Editura Academiei Republicii Socialiste România, vol. I.

Suciu, C. (1968). Dicționar istoric al localităților din Transilvania, Editura Academiei Republicii Socialiste România, vol. II.

Ștef, D. (2016). Dicționar etimologic al localităților din județul Maramureș, Editura Ethnologica, Baia Mare.

TTRT-Sălaj = Tezaurul Toponimic al României. Transilvania: județul Sălaj, Institutul de Lingvistică și Istorie Literară „Sextil

Pușcariu”, Editura Academiei Române, Cluj-Napoca - București, 2006.

TTRT-Valea Hășdății = Loșonți, D. \& Vlad, S. (2006). Tezaurul Toponimic al României. Transilvania. Valea Hăşdății, Editura Academiei Române, București.

TTRT-Valea Ierii = Loșonți, D. \& Vlad, S. (2010). Tezaurul Toponimic al României. Transilvania. Valea Ierii, Editura Academiei Române, București.

Vişovan, Ș. (2005). Monografia toponimică a Văii Izei, Editura Mega, Editura Argonaut, Cluj-Napoca.

Vişovan, Ș. (2008). Toponimia Țării Lăpuşului, Editura Universității de Nord, Baia Mare.

Xenopol, A.D. (1985). Istoria românilor, ediția a IV-a, Editura Științifică și Enciclopedică, București.

\section{Anexa A. Abrevieri}

col. - colectiv

dim. - diminutiv(al)

hip. - hipocoristic

magh. - maghiar

n. fam. - nume de familie

n. p. - nume de persoană n. top. - nume topic

por. - poreclă

prep. - prepoziție

sl. - slav

suprn. - supranume

top. - toponim 